https://helda.helsinki.fi

\title{
Low-temperature long-time cooking of meat: Eating quality and underlying mechanisms
}

\section{Dominguez-Hernandez, Elisa}

\author{
2018-09
}

Dominguez-Hernandez , E , Salaseviciene , A \& Ertbjerg , P 2018 , ' Low-temperature long-time cooking of meat: Eating quality and underlying mechanisms ', Meat Science, vol. 143 , pp. 104-113 . https://doi.org/10.1016/j.meatsci.2018.04.032

http://hdl.handle.net/10138/301302

https://doi.org/10.1016/j.meatsci.2018.04.032

cc_by_nc_nd

acceptedVersion

Downloaded from Helda, University of Helsinki institutional repository.

This is an electronic reprint of the original article.

This reprint may differ from the original in pagination and typographic detail.

Please cite the original version. 


\section{Accepted Manuscript}

Low-temperature long-time cooking of meat: Eating quality and underlying mechanisms

Elisa Dominguez-Hernandez, Alvija Salaseviciene, Per Ertbjerg

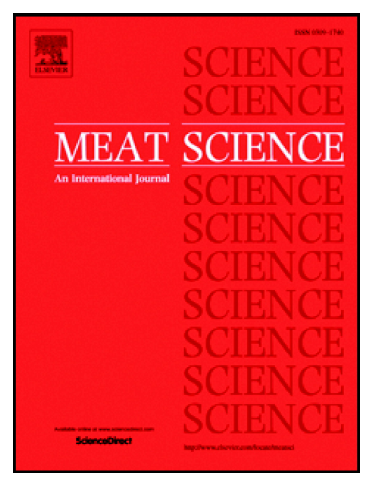

PII:

S0309-1740(17)31528-0

DOI: doi:10.1016/j.meatsci.2018.04.032

Reference:

MESC 7544

To appear in:

Meat Science

Received date:

8 December 2017

Revised date:

25 April 2018

Accepted date:

26 April 2018

Please cite this article as: Elisa Dominguez-Hernandez, Alvija Salaseviciene, Per Ertbjerg , Low-temperature long-time cooking of meat: Eating quality and underlying mechanisms. The address for the corresponding author was captured as affiliation for all authors. Please check if appropriate. Mesc(2018), doi:10.1016/j.meatsci.2018.04.032

This is a PDF file of an unedited manuscript that has been accepted for publication. As a service to our customers we are providing this early version of the manuscript. The manuscript will undergo copyediting, typesetting, and review of the resulting proof before it is published in its final form. Please note that during the production process errors may be discovered which could affect the content, and all legal disclaimers that apply to the journal pertain. 


\section{Low-temperature long-time cooking of meat: Eating quality and underlying mechanisms}

Elisa Dominguez-Hernandeza, Alvija Salaseviciene ${ }^{b}$, Per Ertbjerga, ${ }^{*}$

aDepartment of Food and Nutrition, University of Helsinki, 00014 Helsinki, Finland

bFood Institute, Kaunas University of Technology, 44249, Kaunas, Lithuania

*Corresponding author: Tel.: +358 503183909; E-mail address: per.ertbjerg@helsinki.fi 


\section{Abstract}

Heat treatment of meat at temperatures between 50 and $65^{\circ} \mathrm{C}$, for extended periods of time, is known as low-temperature long-time (LTLT) cooking. This cooking method produces meat that has increased tenderness and better appearance than when cooked at higher temperatures. Public concerns regarding this method have focused on the ability to design heat treatments that can reach microbiological safety. The heat treatment induces modification of the meat structure and its constituents, which can explain the desirable eating quality traits obtained. Denaturation, aggregation, and degradation of myofibrillar, sarcoplasmic and connective tissue proteins occur depending on the combination of time and temperature during the heat treatment. The protein changes, especially in relation to collagen denaturation, along with proteolytic activity, have often been regarded to be the main contributors to the increased meat tenderness. The mechanisms involved and the possible contribution of other factors are reviewed and discussed.

Keywords: Sous-vide, tenderness, juiciness, colour, safety 


\section{Introduction}

Heating of meat modifies its eating quality including texture, colour and flavour (Aaslyng, Bejerholm, Ertbjerg, Bertram, \& Andersen, 2003; Davey \& Niederer, 1977; Kovácsné Oroszvári, Rocha, Sjöholm, \& Tornberg, 2006; Martens, Stabursvik, \& Martens, 1982). In addition, heating of meat increases the digestibility (Qi et al., 2017) and the energy that can be gained upon consumption as also observed when cooking starch-rich foods (Carmody, Weintraub, \& Wrangham, 2011). The rate and extent of these changes is dependent on the amount of heat that is transferred to the meat, and on the heating rate (Cover, 1943; Tornberg, 2005). The ability to exert control over these variables will define to what extent the meat becomes more palatable after cooking (Bertram, Aaslyng, \& Andersen, 2005; Califano, Bertola, Bevilacqua, \& Zaritzky, 1997; Obuz, Dikeman, Erickson, Hunt, \& Herald, 2004). To the consumer, tenderness, juiciness and flavour are the main factors influencing choice and acceptance of cooked meat (Aaslyng et al., 2003; Creed, 1995; Resurreccion, 2004). Therefore, a continuing aim of the meat industry is to find improvements in processing that ensure and enhance these desirable sensory attributes, while still yielding a product that is safe to consume (Banerjee \& Verma, 2015; Holdsworth \& Simpson, 2007). Among those improvements is lowtemperature long-time (LTLT) processing. As the name indicates, the method consists in heating the product to a low endpoint temperature using extended heating times. The cooking temperature is often close to $60^{\circ} \mathrm{C}$ or lower, and the product is kept isothermally for a long time, from hours to even days. Cooking in this way has been long known to produce meat of a high sensorial quality (Christensen et al., 2012; Dinardo, Buck, \& Clydesdale, 1984; Mortensen, Frøst, Skibsted, \& Risbo, 2012), consistently tender and juicy (Bouton \& Harris, 1981; Cover, 1943; Laakkonen, Wellington, \& Sherbon, 1970; Machlik \& 
Draudt, 1963) and have steadily gained popularity in restaurants, centralized kitchens and catering operations (Bañón, Nieto, \& Díaz, 2007).

One of the most popular forms of LTLT cooking is the cook-in-bag technique called sous vide (under vacuum), which applies the principle to vacuum packaged meat with water, or steam, as heating media (Baldwin, 2012; Bañón et al., 2007; Creed, 1995; Myhrvold, Young, Bilet, \& Smith, 2011). LTLT cooking has been said to represent a large contribution to culinary science (Hesser, 2005), but also to the industry of convenience products with extended shelf life (Baldwin, 2012; Bañón et al., 2007; Sheard \& Rodger, 1995).

It is our aim in this review to offer a summary of the current knowledge about LTLT heat treatments, and also to review and discuss the possible mechanisms behind the obtained desirable consumer traits.

\section{The eating quality of LTLT cooked meat}

\subsection{Tenderness}

Cover (1943) reported that beef roasts (triceps brachii and biceps femoris muscles) obtained after cooking at $80^{\circ} \mathrm{C}$ for long time (up to $43 \mathrm{~h}$ ) were always more tender than those cooked at $125^{\circ} \mathrm{C}$ for much shorter time (about one third of the time compared to the lower oven temperature), thus highlighting the importance of a slow heating rate. Later on, Bramblett \& Vail (1964) demonstrated that roasts cooked to a core temperature of $65^{\circ} \mathrm{C}$ had better eating quality (tenderness and overall appearance) when heated at an oven temperature of $68^{\circ} \mathrm{C}$ rather than $93^{\circ} \mathrm{C}$. They also stated that increasing the holding time 
when the core temperature was close to $60^{\circ} \mathrm{C}$ was crucial for obtaining more tender meat. Other studies (Laakkonen,

Wellington, et al., 1970; Machlik \& Draudt, 1963) found that cooking at temperatures close to $60^{\circ} \mathrm{C}$ for extended periods not only avoided the increase in meat toughness observed at higher temperatures, but also improved meat tenderness after $4 \mathrm{~h}$ of

holding. These observations have been further confirmed (Table 1), in beef (Beilken, Bouton, \& Harris, 1986; Bouton \& Harris, 1972a, 1981; Christensen et al., 2013; Dinardo et al., 1984), pork (Becker, Boulaaba, Pingen, Krischek, \& Klein, 2016; Becker, Boulaaba, Pingen, Röhner, \& Klein, 2015; Christensen, Ertbjerg, Aaslyng, \& Christensen, 2011b) and lamb (Roldán, Antequera, Martín, Mayoral, \& Ruiz, 2013).

The consensus is that LTLT cooking results in a greater meat tenderness. However, variations among studies have been reported in relation to the characteristics of the raw materials and the temperature/time combination that was applied. For beef, the longissimus muscle tenderised less than tougher muscles (semitendinosus, semimembranosus, biceps femoris and/or rectus femoris) after $4 \mathrm{~h}$ of holding at $60^{\circ} \mathrm{C}$, as measured by sensory panels and Warner-Bratzler shear force (Dinardo et al., 1984; Laakkonen, Wellington, et al., 1970; Machlik \& Draudt, 1963). Increasing the holding time from 5 to 17 h did not change the shear force values of semitendinosus from slaughter pigs at any temperature between $48^{\circ} \mathrm{C}$ and $63^{\circ} \mathrm{C}$, whereas longissimus tenderised in treatments at $58^{\circ} \mathrm{C}$ and $63^{\circ} \mathrm{C}$ with extended holding (Becker et al., 2015; Christensen et al., 2011b). Sánchez del Pulgar et al. (2012) studied pork masseter muscle, which contains a large amount of connective tissue, and reported that Texture Profile Analysis (TPA) parameters (hardness, adhesiveness, springiness, cohesiveness and chewiness) were not 
affected by an increase in holding time from 5 to $12 \mathrm{~h}$ at $60^{\circ} \mathrm{C}$, but a clear decrease was observed when the meat was cooked at $80^{\circ} \mathrm{C}$ for 12 h (Sánchez del Pulgar, Gázquez, \& Ruiz-Carrascal, 2012).

In the few available studies using young and old animals, age played a role in determining the extent of tenderisation too (Table 1). For example, meat of veal and young bulls (0-12 months) had reduced shear force and adhesion values after less than $4 \mathrm{~h}$ when heated between $50-53^{\circ} \mathrm{C}$ (Beilken et al., 1986; Christensen et al., 2013), while steers and cows (aged between 2 and 17 years) required $55-65^{\circ} \mathrm{C}$ and between 8 and $24 \mathrm{~h}$ of heating to achieve similar reductions in toughness (Bouton \& Harris, 1981; Christensen et al., 2013). We have found only one study in which the age-dependent effect of LTLT treatments in pork was studied; the results showed that toughness of longissimus and semitendinosus muscles from old sows remained essentially unchanged with holding times between 5 and $17 \mathrm{~h}$ in the temperature range between $48^{\circ} \mathrm{C}$ and $63^{\circ} \mathrm{C}$, whereas meat toughness decreased with holding time in muscles from slaughter pigs under similar conditions (Christensen et al., 2011b).

Warner-Bratzler peak force is widely used to represent the overall toughness of meat. However, many studies suggest that the initial yield in the Warner-Bratzler deformation curve reflects the strength of the myofibrils (Beilken et al., 1986; Bouton \& Harris, 1981; Bouton, Harris, Macfarlane, \& Snowden, 1977; Møller, 1981). Using this reasoning, the difference between peak force and initial yield (PF-IY) has been used to obtain information on the mechanical strength of other components of meat. In muscles that have not shortened (sarcomere length of $1.8 \mu \mathrm{m}$ or greater) PF-IY has been attributed to the strength of connective tissue. LTLT treatments have been shown to produce a significant decrease in the PF-IY component 
of the shear force value (Beilken et al., 1986; Bouton \& Harris, 1981; Christensen et al., 2013), suggesting connective tissue weakening. Regarding the mechanical strength of myofibrils, using shear force tenderometer and Warner-Bratzler initial yield, no clear effect from animal age or muscle group has been reported (Beilken et al., 1986; Bouton, Harris, \& Ratcliff, 1981; Davey \& Gilbert, 1974), but in general, the myofibrillar strength was reduced with temperature (between $55-65^{\circ} \mathrm{C}$ ) and time (Beilken et al., 1986; Bouton et al., 1981; Davey \& Gilbert, 1976).

Some authors have tried to explain the changes in beef tenderness following LTLT cooking between 50 and $65^{\circ} \mathrm{C}$ in terms of characteristics of the connective tissue (Table 1). The importance of weakening of the connective tissue as part of the mechanism of tenderisation of LTLT cooked beef is indicated by the clear differences between age groups (mirroring the collagen heat stability) and between types of muscle (reflecting the collagen content). The contribution from connective tissue to tenderisation upon LTLT cooking is likely of a different nature than during long time boiling and stewing of meat (see section 3), where the higher temperatures allow for a complete denaturation of collagen (Micklander, Peshlov, Purslow, \& Engelsen, 2002; Voutila, Ruusunen, \& Puolanne, 2008). However, shear force measurements of cooked meat do not provide a direct measurement of the contribution from the connective tissue, so the results cannot be generalised.

\subsection{Juiciness and cook loss}

Long heating times seem to affect tenderness and juiciness oppositely. LTLT meat was juicier when cooking temperature and holding time were reduced, according to the results of the sensory evaluations available for pork and beef (Becker et al., 2016; 
Christensen et al., 2012; Dinardo et al., 1984; Mortensen et al., 2012; Vaudagna et al., 2002). Given that juiciness and tenderness are the most important sensory attributes in cooked meat, any LTLT process must be designed to obtain optimum values in both traits. Some authors even pointed out how a juicier feel enhanced the perception of tenderness, even when values of shear force were not correspondingly low (Becker et al., 2016; Dinardo et al., 1984). Other parameters could be affected by a low juiciness score. Becker et al. (2016), found that even if pork longissimus muscle cooked at $58^{\circ} \mathrm{C}$ for $20 \mathrm{~h}$ was more tender, panellists described it as "crumbly" and less juicy, when compared to other treatments at low temperature $\left(53^{\circ} \mathrm{C}\right.$ and $20 \mathrm{~h}$, and $60^{\circ} \mathrm{C}$ with no holding time), results that corroborated the trends observed previously by Mortensen et al. (2012) for beef.

Cook loss is, along with shear force measurements, one of the most studied parameters of LTLT meat (Table 1), since it is correlated with juiciness and yield of the final product. For example, Hansen, Knøchel, Juncher, \& Bertelsen (1995) reported yields of $89 \%$ for beef roasts cooked for $5 \mathrm{~h}$ at $62^{\circ} \mathrm{C}$ and $93 \%$ for treatments at $59^{\circ} \mathrm{C}$. Certainly, reducing cook losses is beneficial for the industry and is an advantage of LTLT cooking method when compared to others that used higher temperatures (Dinardo et al., 1984; Roldán et al., 2013; Sánchez del Pulgar et al., 2012).

Care should be applied when comparing cook loss results because of the difference in sample size, heating schedule, raw product history (e.g. freezing-thawing cycles, type of packaging, etc.), given that these variables affect the kinetics of weight and water loss (Oillic, Lemoine, Gros, \& Kondjoyan, 2011). However, for LTLT cooking, some trends can be found in relation to holding time. Laakkonen et al. (1970) reported that the main weight loss in beef (longissimus and semitendinosus muscles) 
occurred during initial heating and the first $3 \mathrm{~h}$ of holding at $60^{\circ} \mathrm{C}$. Beilken et al. (1986) also reported greater cook loss in the temperatures between 50 and $60^{\circ} \mathrm{C}$, with weight changes occurring in the first $8 \mathrm{~h}$ of cooking for veal muscles, and for as long as $48 \mathrm{~h}$ for steer muscles; these age-related differences and cooking-related trends also occurred in other beef studies (Bouton \& Harris, 1981, 1972b; Christensen et al., 2013). Similarly, increased cooking losses for LTLT cooked pork muscles (longissimus and semitendinosus) have been reported when meat was heated between $45^{\circ} \mathrm{C}$ and $60^{\circ} \mathrm{C}(\mathrm{Becker}$ et al., 2016 , 2015; Christensen, Bertram, Aaslyng, \& Christensen, 2011a; Zielbauer, Franz, Viezens, \& Vilgis, 2016). The largest losses occurred at the initial stages of cooking.

Few studies have compared the amount of cook loss with water content measurements. In pork longissimus, LTLT resulted in higher cooking losses as well as lower water content as the temperature was increased from $53^{\circ} \mathrm{C}$ to $58^{\circ} \mathrm{C}(\mathrm{Becker}$ et al., 2016). Similar observations were made for lamb longissimus (Roldán et al., 2013) and pork masseter (Sánchez del Pulgar et al., 2012). However, holding time did not have such a clear effect: while longer times at $60^{\circ} \mathrm{C}$ significantly increased weight losses, the observed reductions in moisture of lamb longissimus (Roldán et al., 2013) and pork masseter muscles were not significant. This was attributed to the loss of other components, such as soluble collagen and various other proteins, as has been observed in beef upon longer isothermal heating at $60^{\circ} \mathrm{C}$ (Christensen et al., 2013; Laakkonen et al., 1970).

The lower cooking losses obtained with LTLT, compared to conventional cooking, are probably due to the combination of processing factors, mainly a low end-point temperature. Furthermore, most LTLT is done using thermostatic water baths, which offer a more uniform heating and a slow average rate of heat penetration (Buck, Hickey, \& Rosenau, 1979), and thus, the 
product can stay in the water for several hours without presenting signs of over-cooking and additional cooking losses

(Baldwin, 2012; Buck et al., 1979). Additionally, LTLT cooking is typically performed on vacuum packaged meat which helps avoiding evaporative losses associated with other cooking methods, like oven roasting (Bañón et al., 2007; Church \& Parsons, 2000; Myhrvold et al., 2011).

\subsection{Colour and flavour}

While long cooking at high temperatures produces meat that is soft but with an unattractive colour, LTLT cooked meat has been shown to be consistently more appealing and uniform in appearance (Bramblett \& Vail, 1964; Dinardo et al., 1984). LTLT cooking also offers more leverage when it comes to controlling the final appearance of meat in terms of doneness (i.e. degree of cooking), which accounts for its popularity among chefs (Baldwin, 2012; Bañón et al., 2007).

Colour and visual appearance are used as indicators of doneness of cooked meat (F.S.I.S., 2011; King \& Whyte, 2006). "Well-done" meat looks pale, dry and greyish-brown, while "rare" meat is reddish-pink and moist (King \& Whyte, 2006; Mortensen, Frøst, Skibsted, \& Risbo, 2015). It has been shown in studies on slow-roasting that a "rare" beef colour occurred from the $6^{\text {th }}$ hour of cooking onwards with temperatures between $50-60^{\circ} \mathrm{C}$ (Bramblett, Hostetler, Vail, \& Draudt, 1959 ;

Bramblett \& Vail, 1964; Cover, 1943; Laakkonen, Wellington, et al., 1970). In sous vide pork and beef, Christensen et al. (2012) observed that a more "done" appearance was obtained by cooking longer (time increased from $6 \mathrm{~h}$ to $30 \mathrm{~h}$ ). 
Most colour measurements agree with visual assessments of LTLT meat's internal colour stability over time. Redness values have been shown to reduce with increasing temperature in the interval from 50 to $65^{\circ} \mathrm{C}$ in, for example, pig and lamb longissimus (Becker et al., 2016; Roldán et al., 2013) and beef semitendinosus (Botinestean, Keenan, Kerry, \& Hamill, 2016; Vaudagna et al., 2002), but also to remain quite constant over time once the core has reached the final temperature. Slightly higher yellowness and lightness values have been found with very prolonged heating times, but often not enough to indicate a "done" appearance in pork (Becker et al., 2015; Christensen et al., 2011a; Sánchez del Pulgar et al., 2012), or lamb (Roldán et al., 2013).

It is widely accepted that most of the volatile aromatic compounds that contribute to the palatability of cooked meat are formed at temperatures above $70^{\circ} \mathrm{C}$, so it would be expected that a pleasant cooked flavour would not develop at a low temperature cooking between 50 and $60^{\circ} \mathrm{C}$ (Calkins \& Hodgen, 2007; Cross, Stanfield, \& Koch, 1976). The meat flavour and taste after cooking at low temperatures is, therefore, a combination of the contribution from fatty acid degradation products and the non-volatile compounds (Aaslyng \& Meinert, 2017). The effect of LTLT cooking at 60 and $80^{\circ} \mathrm{C}$ on the volatile profile of meat has been studied in pork masseter and lamb longissimus muscles (Roldán, Antequera, Armenteros, \& Ruiz, 2014; Roldán, Ruiz, del Pulgar, Pérez-Palacios, \& Antequera, 2015; Sánchez del Pulgar, Roldán, \& Ruiz-Carrascal, 2013), using headspace solid phase micro-extraction followed by mass spectrometry. They reported a decreasing presence of most volatiles derived from lipid oxidation (especially linear aldehydes) as heating intensified (higher temperature and/or longer time) and greater levels of volatile compounds from degradation of amino acids and/or thiamine. 
The development of cooked meat flavour encompasses a complex set of reactions promoted by the amount of heat provided (Calkins \& Hodgen, 2007; Mottram, 1998). Indeed, the observed decrease of carbonyl compounds derived from lipid oxidation points to their implication in further reactions with other compounds (proteins, amino acids, etc.) to produce new, and more desirable volatiles (Roldán et al., 2015; Sánchez del Pulgar et al., 2013). 3-Methylbutanal has been associated with the development of meaty-nutty flavours in dry-cured hams (Ruiz, Ventanas, Cava, Andrés, \& García, 1999), and was also detected in LTLT meat after $24 \mathrm{~h}$ of heating at $60^{\circ} \mathrm{C}$ (Roldán et al., 2015; Sánchez del Pulgar et al., 2013). Cooking time also increased the products from Strecker degradation of other amino acids and thiamine, such as carbon disulfide, dimethyl disulfide, 2-methyl-thiophene, 2-pentylthiophene and benzothiazole. These compounds possess a low odour threshold and are known to provide the meaty, savoury, roast and boiled flavours associated with cooked meat (Calkins \& Hodgen, 2007; Pegg \& Shahidi, 2014).

It is difficult to assess the significance of the detected volatile compounds on the palatability of meat without sensory analyses. A study that dealt with limited flavour descriptors (meaty, bloody, metal and acidic) determined that, even if LTLT treatments $\left(53^{\circ} \mathrm{C}\right.$ and $\left.58^{\circ} \mathrm{C}, 6-30 \mathrm{~h}\right)$ enhanced the perception of meaty flavour in pork and beef, the effects on tenderness and juiciness were of greater importance to the overall acceptance of this type of meat (Christensen et al., 2012). Increasing time (from 3 to $12 \mathrm{~h}$ ) consistently had greater influence than temperature on the perception of brothy and boiled veal flavour/aroma of beef (Mortensen et al., 2012). In agreement, Vaudagna et al. (2002) reported a greater "cooked beef" flavour and aroma scores in meat cooked at $55^{\circ} \mathrm{C}$ for $6.5 \mathrm{~h}$ than at $65^{\circ} \mathrm{C}$ for $1.5 \mathrm{~h}$, while other authors found a decrease in roast flavour 
when cooking at $60^{\circ} \mathrm{C}$ for 2 to $4 \mathrm{~h}$ (Dinardo et al., 1984). It appears that increasing time becomes crucial for the formation of most desirable flavour/aroma traits in a relative narrow temperature range. At the same time, most studies have shown that the intensity of desirable flavour attributes is medium to low when compared to meat cooked at higher temperatures (Roldán et al., 2015; Sánchez del Pulgar et al., 2013), due to the lack of products from Maillard reactions. Therefore, it is common practice prior to serving to sear LTLT meat at high temperatures $\left(130-150^{\circ} \mathrm{C}\right)$ for a few seconds to attain a more appealing appearance (a caramelised surface) and flavour.

\section{Physical and chemical changes during LTLT cooking}

Detailed information on the general effect of heat on meat proteins is described in reviews by Tornberg (2005), focusing on structural and quality changes of meat products, and by Yu, Morton, Clerens, \& Dyer (2017) summarizing the literature on primary-level modifications of proteins due to cooking of meat. Only limited information is available on the heat induced changes of meat components attained by LTLT cooking. A recent study by Zielbauer et al. (2016) systematically investigated the impact of time at different cooking temperatures up to $74^{\circ} \mathrm{C}$. In the following sections, heat-induced modifications are discussed to bring more clarity on the mechanisms behind the improved eating quality of LTLT meat. 


\subsection{Structural changes}

Protein denaturation (see section 3.2) will occur at temperatures as low as 35 to $40^{\circ} \mathrm{C}$, and with increasing temperature there will be a shrinkage in the structure (Warner et al., 2017). As meat temperature is increased from 50 to $60^{\circ} \mathrm{C}$, there is a significant reduction in muscle fibre diameter (Bendall \& Restall, 1983; Palka \& Daun, 1999). At temperatures over $60^{\circ} \mathrm{C}$, shrinkage proceeds, both in diameter and in the longitudinal axis (parallel to the sarcomeres) (Hughes, Oiseth, Purslow, \& Warner, 2014). Bouton, Harris, \& Shorthose (1976) reported increased size reduction as the end-point temperature rose, and indeed larger shrinkage is experienced when heating above $60^{\circ} \mathrm{C}$ (Bendall \& Restall, 1983). This decrease in diameter has been attributed to reduction of the inter-fibre spacing due to myofibrillar protein denaturation and, after that, to the severe contraction of collagen fibres (Bendall \& Restall, 1983; Brüggemann, Brewer, Risbo, \& Bagatolli, 2010). Increasing holding time has a, relatively, smaller effect than increased temperature on diameter changes and, thus in pork longissimus heated at 53, 55, 57 or $59^{\circ} \mathrm{C}$ there were no clear differences in fibre diameter as cooking time was increased from 3 to $20 \mathrm{~h}$ (Christensen et al., 2011a). In lamb longissimus heated at 60,70 or $80^{\circ} \mathrm{C}\left(6,12\right.$ or $24 \mathrm{~h}$ of cooking) the fibres in micrographs were smaller at $60^{\circ} \mathrm{C}$, and there was no effect of time of heating (Roldán et al., 2013). Sarcomere length, a measure of longitudinal shrinkage, was not significantly reduced in pork longissimus (Christensen et al., 2011a), and decreased only slightly in veal pectoralis as temperatures were increased from 50 to $60^{\circ} \mathrm{C}$ and cooking times from 1 to $24 \mathrm{~h}$ (Bouton \& Harris, 1981).

As meat shrinks, fluid is expelled as water and other components such as fat and solubilised proteins (Kovácsné Oroszvári et al., 2006; Sánchez del Pulgar et al., 2012; Tornberg, 2005). Transversal shrinkage of the myofibrils is responsible 
for the majority of the water lost during cooking (Bertram et al., 2005), but, as heating proceeds, denaturation of collagen and longitudinal shrinkage will account for additional losses (Brüggemann et al., 2010; Hughes et al., 2014; Palka \& Daun, 1999). The limited longitudinal shrinkage registered in LTLT cooking can be part of the reason why this process produces smaller losses than other cooking methods in which higher temperatures are used. Also proteolysis by more heat-stable proteolytic enzymes (section 3.3) during the slow heating and long holding times may affect water-holding and cook losses. Thus Kristensen \& Purslow (2001) hypothesized that proteolytic degradation of the cytoskeleton is linked to water-holding and Zeng, Li, \& Ertbjerg (2017) observed degradation of the Z-disk proteins desmin and $\alpha$-actinin following incubation with various proteases, suggesting that swelling of the filament lattice is related to improved water-holding of myofibrils.

Although the direct relationship between dimensional changes and toughness of cooked meat remain unclear, some structural changes of meat components upon heating do affect the tenderness of the end product (Bouton et al., 1977; Lewis \& Purslow, 1989; Mutungi, Purslow, \& Warkup, 1996). Shrinkage of collagen fibres between 50 and $65^{\circ} \mathrm{C}$ decreased the breaking strength of the perimysial connective tissue, while only smaller changes in toughness of myofibrils were observed (Christensen, Purslow, \& Larsen, 2000). At higher temperatures, the overall influence of denaturation of intramuscular connective tissue is tenderising, whereas the structural changes in myofibrils cause toughening (Bouton et al., 1977; Christensen et al., 2000; Lewis \& Purslow, 1989; Mutungi et al., 1996).

Extended holding times have, as outlined in the previous section, been shown to increase meat tenderness. Hours long isothermal heating of meat above $70^{\circ} \mathrm{C}$ is commonly used in order to tenderise meat from old animals or tough cuts due to 
collagen conversion into gelatine (Davey \& Niederer, 1977; Davey, Niederer, \& Graafhuis, 1976), and similar observations during LTLT cooking have led to the suggestion that the tenderisation effect of this cooking method is partly via connective tissue degradation. However, it has also been found that long-time cooking of aged meat decreases the strength of myofibrils by weakening of the forces holding them together, causing an increased level of fragmentation upon shearing (Davey et al., 1976) and, therefore, it is also possible to achieve a high degree of tenderisation in meats with low connective tissue, when cooking at lower temperatures in the range of 50 to $60^{\circ} \mathrm{C}$ (Davey \& Niederer, 1977). The reason for this progressive weakening may be ascribed to the increasing amount of heat delivered, however, proteolysis is also likely to be involved as outlined in section 3.3 .

\subsection{Protein denaturation}

As outlined in the previous sections, the main heat induced modifications occur at the level of muscle proteins, and greatly influence the texture, juiciness/cook loss, colour and flavour of meat. The energy input from cooking causes the proteins to lose their thermodynamic stability and rearrange themselves in the irreversible process of denaturation.

The denaturation temperatures of muscle proteins during ramp heating have been investigated using a variety of techniques, including differential scanning calorimetry (DSC) (Beltrán, Bonnet, \& Ouali, 1992; Berge et al., 2001; Bertola, Bevilacqua, \& Zaritzky, 1994; Martens et al., 1982; Voutila et al., 2008; Wagner \& Anon, 1985), Second Harmonic Generation Microscopy (SHG) (Brüggemann et al., 2010; Sun et al., 2006) and low field Near Magnetic Resonance (NMR) (Bertram et al., 
2005; Christensen et al., 2011a). It has been shown that if meat proteins are heated for prolonged times, then proteins denature even if the cooking temperatures are well below the actual denaturation temperatures otherwise reported (Bertola et al., 1994; Martens et al., 1982; Zielbauer et al., 2016).

\subsubsection{Myofibrillar proteins}

The myofibrils are dynamic protein networks, composed of several different proteins that interact with each other providing stability to the protein complexes and muscle structures (Ertbjerg \& Puolanne, 2017; Fraterman, Zeiger, Khurana, Wilm, \& Rubinstein, 2007). Given that myosin and actin constitute a major part of the myofibrillar proteins, they have been the interest of many studies in relation to protein denaturation.

Myosin is rather thermolabile. The globular heads of the myosin molecule start to denature at $40^{\circ} \mathrm{C}(\mathrm{Warner}, \mathrm{Kauffman}$, \& Greaser, 1997), and structural alterations are observed in myosin subfragment-1 (Liu, Puolanne, \& Ertbjerg, 2014), while heating above $53^{\circ} \mathrm{C}$ marks a more complete denaturation (Berhe, Engelsen, Hviid, \& Lametsch, 2014; Brüggemann et al., 2010). Holding time has some effect on myosin denaturation in combination with the end-point temperature. DSC studies have shown extensive myosin denaturation in meat after $3 \mathrm{~h}$ of holding at $53-54^{\circ} \mathrm{C}$ and only a limited amount of native protein remains after a few minutes of heating at $60^{\circ} \mathrm{C}$ (Berhe et al., 2014; Bertola et al., 1994; Brüggemann et al., 2010). Denaturation of myosin corresponds to structural changes observed with low field NMR, such as reduction in the $\mathrm{T}_{21}$ relaxation time and, consequently, reduced water-protein interactions, shrinkage and increased cook loss in the initial stages of LTLT cooking 
(Bertram et al., 2005; Christensen et al., 2011a). An increasing hydrophobic environment, as a consequence of unfolding of myofibrillar proteins such as myosin has also been reported upon heating between 40 and $65^{\circ} \mathrm{C}$, and this change can also affect the water binding of cooked muscle (Berhe et al., 2014; Chelh, Gatellier, \& Santé-Lhoutellier, 2006; Santé-Lhoutellier, Théron, Cepeda, Grajales, \& Gatellier, 2008).

Actin has been reported to require somewhat high temperatures, between 68 and $80^{\circ} \mathrm{C}$, before it starts to denature (Berhe et al., 2014; Bertola et al., 1994; Martens et al., 1982). However, DSC studies have shown that the relative amount of native actin in beef and pork appear to decrease with extended holding time, even at temperatures below $60^{\circ} \mathrm{C}(\mathrm{Bertola}$ et al., 1994; Christensen et al., 2011a, 2013; Martens et al., 1982; Zielbauer et al., 2016). Denaturation of actin could thus be a factor causing some of the reduction in fibre diameter observed under prolonged isothermal heating.

Myofibrillar protein denaturation is associated with toughening upon traditional cooking of meat, especially above $60^{\circ} \mathrm{C}$ (Bertola et al., 1994; Martens et al., 1982). It remains a question why the extensive denaturation of actin during LTLT cooking apparently does not cause increased toughness, as observed in other more severe thermal treatments (Califano et al., 1997; Cheng \& Parrish, 1979; Martens et al., 1982). Furthermore, some denaturation phenomena of myofibrillar proteins (like their unfolding and aggregation dynamics) under long isothermal heating have not been studied to the same extent as in traditional high temperature cooking, so their contribution to properties of LTLT cooked meat is not well understood. 


\subsubsection{Collagen}

The connective tissue and associated collagen is also irreversibly modified as the temperature is raised. Shrinkage of collagen fibrils has been observed to occur at $57^{\circ} \mathrm{C}$ (Brüggemann et al., 2010), but there are indications that structural deformations can occur even at lower temperatures (e.g. $55^{\circ} \mathrm{C}$ ) (Sun et al., 2006). However, the shortening occurring at temperatures above $64^{\circ} \mathrm{C}$ is much more extensive, and coincides with an increase in cook loss and a reduction in the breaking strength of collagen (Bailey \& Light, 1989). When heated to temperatures of $58-64^{\circ} \mathrm{C}$ the collagen molecule undergoes a transition from the helical (crystalline) state to a randomly coiled (amorphous) structure (Lepetit, 2007). The transition is caused by breakage of hydrogen bonds and, consequently, there will be reduction of water-protein interactions, loosening of the fibrillar structure, and contraction of the collagen molecule. Unrestrained collagen fibres shrink when heated to temperatures of 60 to $70^{\circ} \mathrm{C}$ (Tornberg, 2005), denaturation then proceeds into granulation, increased solubilisation and then gelatinisation, in connection with the breaking of intermolecular bonds by increasing heat (Palka, 2003; Palka \& Daun, 1999; Voutila et al., 2008). Although complete gelatinisation occurs at temperatures above $65^{\circ} \mathrm{C}$ at the heating rate of $5^{\circ} \mathrm{C} / \mathrm{min}$. Brüggemann et al. (2010) and Voutila et al. (2008) found (using a slower heating rate), that most collagen fibres in the epimysium melt at $59^{\circ} \mathrm{C}$. These changes are strongly considered tenderising, but gelation of collagen has been also proposed as a process which can account for increased water holding in temperatures between 45 and $60^{\circ} \mathrm{C}$ (Zielbauer et al., 2016)

As holding time increases at temperatures close to $60^{\circ} \mathrm{C}$, a continuous degradation of collagen occurs, measurable in the reduction of the second endothermic peak of cooked meat after $3 \mathrm{~h}$ (Bertola et al., 1994) and in the greater amount of 
solubilised collagen expelled in cook loss after hours of isothermal heating (Christensen et al., 2011b, 2013; Dinardo et al., 1984). It is uncertain how extensive the solubilisation/gelatinisation is at low temperatures, as some collagen fibrils are known to retain a recognisable form even after heating for extended cooking times $\left(60^{\circ} \mathrm{C}\right.$ and $\left.12 \mathrm{~h}\right)$ (García-Segovia, AndrésBello, \& Martínez-Monzó, 2007; Sánchez del Pulgar et al., 2012; Voutila et al., 2008). In LTLT cooking, positive correlations between solubilised collagen and tenderness in pork and beef (Christensen et al., 2011b, 2013), suggested that collagen denaturation was involved in the tenderizing mechanism.

\subsubsection{Myoglobin and other sarcoplasmic proteins}

Although the sarcoplasmic proteins do not possess structural function in muscle, they are responsible for the colour of cooked meat and, to some extent, its texture (Martens et al., 1982; Tornberg, 2005) and water-holding (Liu, Arner, Puolanne, \& Ertbjerg, 2016). The complex mixture of water-soluble proteins denatures over a wide range of temperatures, from approximately 40 to $90^{\circ} \mathrm{C}$ (Davey \& Gilbert, 1974), according to solubility measurements.

Myoglobin starts denaturing between $55^{\circ} \mathrm{C}$ and $65^{\circ} \mathrm{C}$ in meat, reaching a maximum by $75-80^{\circ} \mathrm{C}$ (Hunt, Sørheim, \& Slinde, 1999 ; Mancini \& Hunt, 2005). Of the three myoglobin forms, deoxymyoglobin has shown the greatest heat stability, followed by oxymyoglobin and then metmyoglobin (Hunt et al., 1999). The main denaturation phenomenon in myoglobin is the unfolding of the globin moiety to form ferrohemochrome (pink/red) or ferrihemochrome (brown) pigments, depending on the oxidation state of the native protein (Hunt et al., 1999; Trout, 1989). The denaturation of globin leaves the heme site more vulnerable to 
oxidation, and, therefore, ferrohemochrome will often turn into the ferric form (ferrihemochrome), which is associated with a "done" appearance after extensive cooking (Hunt et al., 1999; King \& Whyte, 2006; Mancini \& Hunt, 2005; Trout, 1989). In this context, the greater proportion of red-pink pigments found in LTLT cooked meats has been attributed to the presence of higher amounts of native oxymyoglobin, or deoxymyoglobin, because of the mild heat treatment and the oxygen-free environment provided by vacuum packaging.

It has been proposed that the transition of meat into a gel is a reason for the increase in tenderness between 50 and $65^{\circ} \mathrm{C}$ (Davey \& Gilbert, 1974; Tornberg, 2005). During LTLT cooking, solubilised collagen and sarcoplasmic proteins could deposit inside myofibres and form a gel, which could be one mechanism behind the changes in texture. In agreement, it has been observed in sous vide cooking that meat appears more gel-like as cooking intensifies, with a consequent reduction in toughness (García-Segovia et al., 2007; Roldán et al., 2013; Sánchez del Pulgar et al., 2012). Micrographs of LTLT pork masseter showed that the amount of a homogeneous substance became more obvious as time was increased from 5 to $12 \mathrm{~h}$ at $60^{\circ} \mathrm{C}(\mathrm{Sánchez}$ del Pulgar et al., 2012). Furthermore, images of lamb longissimus showed that, meat fibres cooked for 24 h, even at the lowest temperature $\left(60^{\circ} \mathrm{C}\right)$, seemed swollen, and the structure of the meat more compact, with granular deposits between them (Roldán et al., 2013). Gelation of myosin and sarcoplasmic proteins may also be a factor influencing the complex relationships observed between cook loss and protein denaturation in pork (Zielbauer et al., 2016). 


\subsection{Proteolysis}

It has long been suggested proteolysis acts as an auxiliary mechanism to heat in the degradation of collagen during mild heat treatments, where a combination of low temperature and a slow heating rate are applied (Laakkonen, Sherbon, \& Wellington, 1970; Penfield \& Meyer, 1975).

Laakkonen, Sherbon, et al. (1970) found residual collagenolytic activity during LTLT treatments of aged meat, but they also reported that the detected activity was too great to be solely attributed to collagenase, which suggested involvement of other proteolytic systems. Due to the thermal stability of cathepsins, they were proposed as an alternative system as they were active during long time cooking (Davey \& Gilbert, 1976; Davey \& Niederer, 1977). These endopeptidases are contained within lysosomes but, upon ageing or heating, they are released and diffuse into meat structures (Christensen, Larsen, Ertbjerg, \& Purslow, 2004; Ertbjerg, Mielche, Larsen, \& Møller, 1999; Spanier, McMillin, \& Miller, 1990).Their proteolytic activity is broad, as they are capable of degrading myofibrillar and connective tissue proteins (Agarwal, 1990; Baron, Jacobsen, \& Purslow, 2004; Bechet, Tassa, Taillandier, Combaret, \& Attaix, 2005; Burleigh, Barrett, \& Lazarus, 1974).

Only recently, residual cathepsins B and L activity have been measured in the cook loss of meat heated for a long time at low temperature. Residual cathepsin activity measured in cooked pork muscles (semitendinosus and longissimus) increased with temperature from 48 to $58^{\circ} \mathrm{C}$ (Christensen et al., 2011b), and to a lesser extent by increasing holding time from 5 to $17 \mathrm{~h}$. Based on similar findings, Ertbjerg, Christiansen, Pedersen, \& Kristensen (2012) suggested the possibility of heat activation of pro-cathepsins during thermal processing. According to Burleigh et al. (1974) and Etherington, (1976) cathepsins can 
destabilise native collagen, and also degrade thermally weakened collagen into peptides, that can be further attacked by other enzymes. Proteolysis in conjunction with heat denaturation, therefore, could act synergistically to produce the increased weakening of collagen and tenderisation seen in LTLT treatments.

The contribution of proteolysis to myofibrillar degradation during LTLT treatment may be different from that postulated above and is not yet clearly understood. Calpains are unlikely to be responsible for the tenderisation during prolonged holding times, as calpain-2 starts to lose activity at $40^{\circ} \mathrm{C}$, and is rapidly inactivated at $55^{\circ} \mathrm{C}$ (Ertbjerg et al., 2012 ). Heat-induced denaturation of myofibrillar proteins could facilitate proteolysis by changing the protein conformation which in turn leads to a mechanical weakening of the structure during prolonged heating. But the dynamics in myofibrils could be more complex than those of collagen as heat denaturation progresses. It has been found that the exposure of hydrophobic sites during the unfolding of proteins can enhance proteolysis by systems like the proteasome (Pacifici, Kono, \& Davies, 1993), however, there are also indications that intense aggregation of muscle proteins can be detrimental and even inhibiting to proteolytic action (Santé-Lhoutellier, Astruc, Marinova, Greve, \& Gatellier, 2008; Santé-Lhoutellier, Théron, et al., 2008).

\section{Safety and stability of LTLT products}

The advantages offered by LTLT sous vide in terms of sensorial quality may be overshadowed by concerns relating to the microbiological safety and shelf stability of meat cooked at very low temperatures. This is of particular importance since meat 
is an ideal growth medium for many organisms, including pathogens like Salmonella, Listeria monocitogenes, Escherichia coli,

\section{Clostridium perfringens.}

Traditionally, to obtain safe meat, government agencies recommend cooking the product just until the slowest heating point (i.e. the geometric centre) reaches temperatures between $63^{\circ} \mathrm{C}$ and $71^{\circ} \mathrm{C}$. Using the concept of equivalent processing, when cooking at lower temperatures, longer holding times are required to achieve successful inactivation, thus LTLT processes can be designed to be safe in terms of a target microorganism. For example, Vaudagna et al. (2002) calculated pasteurisation values for $6.5 \mathrm{~h}$ of cooking at $50^{\circ} \mathrm{C}$ and $55^{\circ} \mathrm{C}$ to be equivalent to $P_{70}^{10}=5.99 \mathrm{~min}$ and $P_{70}^{10}=17.77 \mathrm{~min}$, and sufficient to inactivate L. monocitogenes, a fairly heat tolerant pathogen that is commonly used as a safety indicator for lowtemperature long-time heat treatments.

\subsection{Microbial safety}

Total plate counts and total viable cell counts were used to evaluate LTLT processes applied in beef $\left(50-62^{\circ} \mathrm{C}\right)$, resulting in significant reductions of microorganism counts for mesophiles and psychrotrophs after cooking (Botinestean et al., 2016; Hansen et al., 1995; Vaudagna et al., 2002). Counts also showed to be significantly lower after cooking pork at $53^{\circ} \mathrm{C}$ for several hours (Becker et al., 2015; Salaseviciene, Vaiciulyte-Funk, \& Koscelkovskienè, 2014) in terms of Enterobacteriaceae and mesophiles. Roldán et al. (2013) reported that at least $6 \mathrm{~h}$ of cooking lamb at $60^{\circ} \mathrm{C}$ was sufficient to reduce counts of 
microorganisms (lactic acid bacteria, gram positive cocci, Enterobacteriaceae, coliforms, Bacillus thermosphacta, L. monocitogenes and Salmonella typhimurium) found in raw lamb loins to values lower than $1 \mathrm{CFU} / \mathrm{g}$.

Assaying specific pathogens, Christensen et al. (2012) and Gunvig \& Jacobsen (2012) agreed that at prolonged holding time at $53^{\circ} \mathrm{C}$ is sufficient to achieve 5-log to $6.7-\log (5 \mathrm{D}$ to $6.7 \mathrm{D})$ reduction of Listeria monocitogenes in beef. For pork, Becker, Boulaaba, Pingen, Röhner, \& Klein (2015) inoculated longissimus muscles with various pathogens (Salmonella Enteritidis, L. monocitogenes and E. coli (0157:H7)) that were inactivated at levels of $5 \mathrm{D}$ after $10 \mathrm{~h}$ at $53^{\circ} \mathrm{C}$,; the same reduction for Salmonella under LTLT at $53^{\circ} \mathrm{C}$ and $58^{\circ} \mathrm{C}$ was also mentioned by Christensen et al. (2012) for pork semitendinosus.

Smith, Evans, \& Buck (1981), evaluated growth and survival of Clostridium perfringens in beef muscles (semimembranosus, semitendinosus, biceps femoris, quadriceps femoris and longissimus) cooked to a core temperature of $60^{\circ} \mathrm{C}$ with increased holding times. They found that not only vegetative cell numbers decrease by 3-log cycles (3D) with minimal holding, but also lethal effects start at lower temperatures $\left(48.9^{\circ} \mathrm{C}\right)$ when heating rates are elevated. The authors recommended a minimum of $2.3 \mathrm{~h}$ holding time in a water bath for a 12D reduction, ensuring both safety and without loss of quality when initial counts are higher than expected (as tested with inoculated roasts at $10^{6}$ cells/g). Vaudagna et al. (2002) also recommended the use of treatments more severe than $50^{\circ} \mathrm{C}$ and $6.5 \mathrm{~h}$ of holding to achieve the minimum of a $6 \mathrm{D}$ reduction of this organism, which can produce food poisoning. Recently, the growth and inactivation of $C$. perfringens was evaluated under different rates of heating in pork cooking; slow heating resulted in greater heat tolerance and, therefore, longer isothermal cooking at $53^{\circ} \mathrm{C}$ was needed 
to inactivate the microorganism and reduce the counts below detection levels (Duan, Hansen, Hansen, Dalgaard, \& Knøchel, 2016).

Mesophiles like Salmonella spp. and E. coli (0157:H7) are not pathogens of concern in LTLT products since they are not heat tolerant and cannot reproduce under well-kept refrigeration conditions. They are rather used, along with Enterobacteriaceae, as indicators of hygienic processing conditions. However, Becker, Boulaaba, Pingen, Röhner, \& Klein (2015) were able to qualitatively isolate $E$. coli after cooking at $53^{\circ} \mathrm{C}$ for three hours, and recommended validation of all treatments before stating their safety. Ensuring the safety of a process is of particular importance when LTLT meat products are to be served to immuno-compromised costumers, such as the elderly (Botinestean et al., 2016).

Given the possibility of mild heat treatments creating thermal resistance in some microbes (Duan et al., 2016; Hansen \& Knøchel, 1996) as well as the observed variations in the logarithmic reductions, it is highly advisable to use raw meat with low initial counts of microorganisms, follow hygienic guidelines to prevent cross contamination, consider the use of preserving additives (Juneja, Bari, Inatsu, Kawamoto, \& Friedman, 2009), and avoid temperature abuse of both cooked and raw meat (Baldwin, 2012; FDA, 2011; Hyytia-Trees et al., 2000; Vaudagna et al., 2002). Purslow (2016) pointed out that the parasites Trichinella spiralis and Toxoplasma gondii present a concern for the use of low temperature cooking of pork in some geographical areas such as Argentina. Safety in this case would be dependent on the quality of the raw materials, so careful inspection to ensure the absence of parasites should be a priority in those countries. 
Inactivation of Clostridium spp. is relevant because some species have the ability to germinate and grow in refrigeration when there is temperature abuse and little or no additives are present (salts, for example), thus causing package swelling and toxin formation (Hansen et al., 1995; Juneja \& Marmer, 1998). For LTLT meat that is not to be served immediately, and rather placed in cold storage (cook- chill approach) the risk posed by toxin-producing nonproteolytic Clostridium botulinum, given the heat tolerance of its spores, would be of concern. Thermal treatments at temperatures above $60^{\circ} \mathrm{C}$, commonly applied in sous vide ready meals, are often unable to achieve a safe reduction of $C$. botulinum spores (Hansen et al., 1995; Hyytia-Trees et al., 2000; Vaudagna et al., 2002). Indeed, the use of higher temperatures (above $80^{\circ} \mathrm{C}$ ) for close to $30 \mathrm{~min}$ is recommended in order to obtain a 6D reduction of this target microorganism (Holdsworth \& Simpson, 2007; Lindström et al., 2001; Sheard \& Rodger, 1995). However, for the reasons explained in the previous sections, this approach to cooking can cause deterioration of the sensorial quality of meat hence an effective control of the storage temperature (under $4^{\circ} \mathrm{C}$ ) should be applied, as well as limiting the shelf life of the product to a few days, to decrease the risk of spore germination (Baldwin, 2012; Graham, Mason, Maxwell, \& Peck, 1997; Hansen et al., 1995; Peck \& Stringer, 2005; Vaudagna et al., 2002).

\subsection{Stability}

Spoilage and storage stability are also concerns for LTLT cook-chill meat. In successful low temperature cooking and during storage $\left(\leq 5^{\circ} \mathrm{C}\right)$, some meat borne pathogens (Listeria, E. coli and B. thermosphacta) have not been detected, and even though microbial counts have shown increases, the pathogens were always below the detection limits, ensuring 
microbiological stability of cooked beef for 35 days (Hansen et al., 1995) and 55 days (Vaudagna et al., 2002), and during 14 days for pork (Salaseviciene et al., 2014).

The low cooking temperatures used in LTLT influences the nutritional value of the meat and thus vitamin $\mathrm{B}_{12}$ has been reported to be better retained (Rinaldi et al., 2014). Few studies have addressed the sensorial and chemical deterioration of LTLT meat under storage. 'Blood' and 'metal' were common descriptors used for off-flavours and off-odours of beef roasts, which appear after 21 and 23 days of storage (Hansen et al., 1995; Vaudagna et al., 2002). Vaudagna et al. (2002) reported growing rates of lipid oxidation (as measured by Thiobarbituric acid reactive substances, TBARS) from the $13^{\text {th }}$ day of storage onwards, in beef cooked at $65^{\circ} \mathrm{C}$, and from the $21^{\text {st }}$ day onwards in the treatments at $55^{\circ} \mathrm{C}$. Grigioni, Margaría, Pensel, Sánchez, \& Vaudagna (2000) also reported significant increments in TBARS for LTLT cooked meat $\left(50^{\circ} \mathrm{C}, 6.5 \mathrm{~h}\right)$ from day 20 of storage to day 34. Both studies found similar changes in the scores for warmed-over flavour (WOF) measured by either sensory panel or electronic nose. Hansen et al. (1995) found low levels of TBARS and WOF for beef roasts, which did not increase for up to day 34 of storage, although they noted changes in texture after 10 days in meat cooked at $59^{\circ} \mathrm{C}$. The authors also stated that, in their study conditions, the odour and chemical changes were minor if the package was kept intact but increased dramatically after opening and slicing.

The results presented in these studies seem to indicate that the sensorial deterioration is also a limiting factor for determining the shelf life of LTLT cook-chill meat products, in agreement with observations about higher temperature sous vide processes (Armstrong \& McIlveen, 2000; Díaz, Nieto, Garrido, \& Bañón, 2008). 


\section{Conclusions}

Low-temperature Long-time cooking offers multiple advantages to traditional high temperature cooking. The ability to reach thermal equilibrium with the heating medium allows for a uniform eating quality and reduces the risk of overcooking, as well as allowing more control over the doneness of the product. The main advantage is the possibility of obtaining more tender meat, when the right combinations of time and temperature are applied, regardless of the characteristics of the raw meat (species, type of muscle or age of the animal). The mechanisms behind this feature of LTLT cooking are not yet completely understood. Evidence has suggested that the observed tenderisation under LTLT cooking, is a consequence of the complex interplay between heat-induced protein denaturation and proteolysis of connective tissue and, possibly, myofibrillar structures.

Over the years, concerns about the safety of LTLT meat products have arisen. It is now known that mesophilic bacteria are inactivated by some of the mildest temperatures applied, provided the holding time is sufficiently long. However, additional measures are required to avoid the risks posed by the survival of more thermoresistant pathogens.

\section{Acknowledgments}

The CONACYT-CONCYTEP Human Resources Development Programme, and to the government of Ahuazotepec, Mexico, are acknowledged for the funding awarded to E. Dominguez-Hernandez. 
Table 1. Synopsis of studies investigating tenderness and cook loss during LTLT cooking of meat. WB-SF: Warner-Bratzler shear force; WB-PF: Warner-Bratzler peak force; WB-IY: Warner-Bratzler initial yield.

\begin{tabular}{|c|c|c|c|c|c|}
\hline \multirow[b]{2}{*}{ Reference } & \multicolumn{2}{|c|}{ Cooking conditions } & \multirow[b]{2}{*}{ Muscles } & \multirow[b]{2}{*}{ Measurements } & \multirow[b]{2}{*}{ Observations/Highlights } \\
\hline & $\begin{array}{c}\text { Temperature } \\
\left({ }^{\circ} \mathrm{C}\right)\end{array}$ & $\begin{array}{l}\text { Holding } \\
\text { Time (h) }\end{array}$ & & & \\
\hline \multicolumn{6}{|l|}{ Beef } \\
\hline $\begin{array}{l}\text { Laakkonen, } \\
\text { Wellington, et al. } \\
\text { (1970) }\end{array}$ & 60 & $0-6$ & $\begin{array}{l}\text { Longissimus, } \\
\text { semitendinosus, } \\
\text { rectus femoris }\end{array}$ & WB-SF, weight loss & $\begin{array}{l}\text { Slow heating and holding at } 60^{\circ} \mathrm{C} \\
\text { produce increased tenderness. } \\
\text { Weight losses are mainly present } \\
\text { during the heating phase. }\end{array}$ \\
\hline $\begin{array}{c}\text { Bouton and Harris } \\
\text { (1972) }\end{array}$ & $\begin{array}{c}40,50,60,70 \\
75 \text { and } 90\end{array}$ & $1-16$ & $\begin{array}{l}\text { Pectoralis, biceps } \\
\text { femoris, } \\
\text { semitendinosus, } \\
\text { semimembranosus, } \\
\text { psoas major } \\
\end{array}$ & $\begin{array}{c}\text { WB-SF, } \\
\text { compression, } \\
\text { extension/ } \\
\text { adhesion, weight } \\
\text { loss, expressed juice } \\
\end{array}$ & $\begin{array}{l}\text { For tenderisation, young animals } \\
\text { require milder treatments than } \\
\text { older ones. }\end{array}$ \\
\hline Davey (1976) & $\begin{array}{c}30,60,65 \text { and } \\
70\end{array}$ & & \multirow[b]{2}{*}{ Sternomandibularis } & \multirow{2}{*}{$\begin{array}{l}\text { Tenderometer, } \\
\text { standardized } \\
\text { shearing }\end{array}$} & $\begin{array}{l}\text { The tenderisation occurring as } \\
\text { holding time increases }\left(60-65^{\circ} \mathrm{C}\right) \text { is } \\
\text { due to a biochemical reaction } \\
\text { weakening the myofibrils. }\end{array}$ \\
\hline Davey (1977) & & $1-9$ & & & $\begin{array}{c}\text { Tenderising at } 65^{\circ} \mathrm{C} \text { occurs rapidly, } \\
\text { with additional shear force } \\
\text { reductions after long isothermal } \\
\text { heating. }\end{array}$ \\
\hline $\begin{array}{l}\text { Bouton and Harris } \\
\text { (1981) } \\
\text { Bouton et al. (1981) }\end{array}$ & 50 and 60 & 1 and 24 & $\begin{array}{l}\text { Pectoralis profundus, } \\
\text { semitendinosus, } \\
\text { longissimus, biceps } \\
\text { femoris }\end{array}$ & $\begin{array}{c}\text { WB-PF, } \\
\text { compression, } \\
\text { adhesion, weight } \\
\text { loss }\end{array}$ & $\begin{array}{c}\text { Degradation of collagen can explain } \\
\text { the tenderisation at } 50-60^{\circ} \mathrm{C} \text {, given } \\
\text { age dependence. No clear } \\
\text { myofibrillar involvement in } \\
\text { tenderisation. }\end{array}$ \\
\hline $\begin{array}{l}\text { Dinardo et al. } \\
\text { (1984) }\end{array}$ & 60 & $\begin{array}{c}0,2 \text { and } \\
4\end{array}$ & $\begin{array}{l}\text { Longissimus, biceps } \\
\text { femoris, } \\
\text { semitendinosus, }\end{array}$ & WB-SF, weight loss & $\begin{array}{l}\text { Cooking in a waterbath allows for a } \\
\text { more uniform doneness. Collagen } \\
\text { solubilisation increased with }\end{array}$ \\
\hline
\end{tabular}




\begin{tabular}{|c|c|c|c|c|c|}
\hline & & & semimembranosus, & & extended holding time at $60^{\circ} \mathrm{C}$. \\
\hline Hansen et al. (1995) & 59 and 62 & 5 & Semitendinosus & WB-SF, weight loss & $\begin{array}{l}\text { Yield is higher at } 59^{\circ} \mathrm{C} \text {. Shear force } \\
\text { was lower at } 62^{\circ} \mathrm{C} \text {. Both parameters } \\
\text { changed with storage time. }\end{array}$ \\
\hline Beilken et al. (1986) & $\begin{array}{c}50,55,60 \text { and } \\
65\end{array}$ & $\begin{array}{c}0.5,1,2, \\
4 \text { and } 8 \\
1,24 \text { and } \\
48\end{array}$ & Semimembranosus & $\begin{array}{l}\text { WB-PF and WB- } \\
\text { weight loss }\end{array}$ & $\begin{array}{l}\text { A combination of connective tissue } \\
\text { degradation and ageing of the } \\
\text { myofibrillar structure takes place at } \\
55-60^{\circ} \mathrm{C} \text { and extended holding. }\end{array}$ \\
\hline $\begin{array}{c}\text { Vaudagna et al. } \\
(2002)\end{array}$ & $\begin{array}{c}50,55,60 \text { and } \\
65\end{array}$ & $\begin{array}{l}1.5,3 \\
4.5 \text { and } \\
6.5\end{array}$ & & WB-SF, weight loss & $\begin{array}{l}\text { As temperature raises from } 50 \text { to } \\
65^{\circ} \mathrm{C} \mathrm{SF} \text { decreases and cook loss } \\
\text { increases. Studied times do not have } \\
\text { a significant effect. }\end{array}$ \\
\hline $\begin{array}{c}\text { Christensen et al. } \\
\text { (2013) }\end{array}$ & $\begin{array}{c}53,55,58 \text { and } \\
63\end{array}$ & 5 and 17 & emitendinosus & $\begin{array}{l}\text { WB-PF, WB-IY, } \\
\text { weight loss }\end{array}$ & $\begin{array}{l}\text { Reduction of SF is caused by } \\
\text { weakening of connective tissue. } \\
\text { Increased solubilisation of collagen } \\
\text { can be related to Cathepsin activity. }\end{array}$ \\
\hline $\begin{array}{l}\text { Botinestean et al. } \\
\qquad(2016)\end{array}$ & & & Semitendinosus & WB-SF, TPA & $\begin{array}{l}\text { Sous vide at low temperatures led to } \\
\text { decreases in SF. Hardness and } \\
\text { chewiness were also reduced when } \\
\text { cooking at } 60^{\circ} \mathrm{C} \text {. Appearance was } \\
\text { also improved. }\end{array}$ \\
\hline \multicolumn{6}{|l|}{ Pork } \\
\hline $\begin{array}{c}\text { Christensen et al. } \\
\text { (2011b) }\end{array}$ & $\begin{array}{c}48,53,58 \text { and } \\
63\end{array}$ & $\begin{array}{c}0,5 \text { and } \\
17\end{array}$ & $\begin{array}{l}\text { Longissimus, } \\
\text { semitendinosus }\end{array}$ & WB-SF, weight loss & $\begin{array}{l}\text { Lower toughness and increased cook } \\
\text { loss were more apparent between } 53 \\
\text { and } 58^{\circ} \mathrm{C} \text {. Solubilisation of collagen } \\
\text { required more time. Sows require } \\
\text { more time and temperature to } \\
\text { tenderise. }\end{array}$ \\
\hline
\end{tabular}




\begin{tabular}{|c|c|c|c|c|c|}
\hline & & & & & \\
\hline $\begin{array}{c}\text { Christensen et al. } \\
\text { (2011a) }\end{array}$ & $\begin{array}{c}53,55,57 \text { and } \\
59\end{array}$ & 3 and 20 & Longissimus & Weight loss & $\begin{array}{l}\text { Prolonged cooking }(20 \mathrm{~h}) \text { results in } \\
\text { decreasing water-protein interactions } \\
\text { and higher cook loss. }\end{array}$ \\
\hline $\begin{array}{l}\text { Sánchez del Pulgar } \\
\text { et al. (2012) }\end{array}$ & 60 and $80^{\circ} \mathrm{C}$ & 5 and 12 & Masseter & $\begin{array}{l}\text { TPA, weight loss, } \\
\text { moisture content }\end{array}$ & $\begin{array}{l}\text { Cooking at low temperature produces } \\
\text { lower cook losses and helps } \\
\text { preserving water. Samples at } 60^{\circ} \mathrm{C} \\
\text { present broken but not completely } \\
\text { denatured collagen fibres. }\end{array}$ \\
\hline Becker et al. (2015) & 53 and 58 & $\begin{array}{l}10,20 \\
\text { and } 30\end{array}$ & Longissimus & WB-SF, weight loss & $\begin{array}{c}\text { After 30h of heating there are no } \\
\text { significant decreases in shear force or } \\
\text { increases in cook loss. }\end{array}$ \\
\hline $\begin{array}{c}\text { Zielbauer et al. } \\
\text { (2016) }\end{array}$ & $\begin{array}{c}45,51,60 \text { and } \\
74\end{array}$ & Up to 48 & s major & Weight loss & $\begin{array}{l}\text { Protein denaturation and water } \\
\text { binding show similar trends with } \\
\text { respect to time and temperature. } \\
\text { Shrinkage and gel formation kinetics } \\
\text { follow different time scales than } \\
\text { water loss. }\end{array}$ \\
\hline \multicolumn{6}{|l|}{ Lamb } \\
\hline Roldán et al. (2013) & 60,70 and 80 & $\begin{array}{c}\text { 6, } 12 \text { and } \\
24\end{array}$ & Longissimus & $\begin{array}{l}\text { TPA, weight loss, } \\
\text { moisture content, } \\
\text { WB-SF }\end{array}$ & $\begin{array}{l}\text { Hardness decreases with time } \\
\text { indicate disintegration of the } \\
\text { connective tissue surrounding the } \\
\text { fibres. }\end{array}$ \\
\hline
\end{tabular}




\section{References}

Aaslyng, M. D., Bejerholm, C., Ertbjerg, P., Bertram, H. C., \& Andersen, H. J. (2003). Cooking loss and juiciness of pork in relation to raw meat quality and cooking procedure. Food Quality and Preference, 14, 277-288.

Aaslyng, M. D., \& Meinert, L. (2017). Meat flavour in pork and beef - From animal to meal. Meat Science, 132, $112-117$.

Agarwal, S. K. (1990). Proteases cathepsins. A view. Biochemical Education, 18, 67-72.

Armstrong, G. A., \& McIlveen, H. (2000). Effects of prolonged storage on the sensory quality and consumer acceptance of sous vide meat-based recipe dishes. Food Quality and Preference, 11, 377-385.

Bailey, A. J., \& Light, N. D. (1989). The role of connective tissue in determining the textural quality of meat. In: Connective Tissue in Meat and Meat Products, (pp. 170-194). London and New York: Elsevier Science Publishers.

Baldwin, D. E. (2012). Sous vide cooking: A review. International Journal of Gastronomy and Food Science, 1, 15-30.

Banerjee, R., \& Verma, A. (2015). Minimally Processed Meat and Fish Products. In M. W. Siddiqui \& M. S. Rahman (Eds.),

Minimally Processed Foods (pp. 193-250). Springer International Publishing.

Bañón, S., Nieto, G., \& Díaz, P. (2007). Aplicaciones de la tecnología sous vide en la elaboración de platos preparados cárnicos para catering. Eurocarne, 17(155), 109-115.

Baron, C. P., Jacobsen, S., \& Purslow, P. P. (2004). Cleavage of desmin by cysteine proteases: Calpains and cathepsin B. Meat Science, 68, 447-456.

Bechet, D., Tassa, A., Taillandier, D., Combaret, L., \& Attaix, D. (2005). Lysosomal proteolysis in skeletal muscle. International Journal of Biochemistry \& Cell Biology, 37, 2098-2114.

Becker, A., Boulaaba, A., Pingen, S., Krischek, C., \& Klein, G. (2016). Low temperature cooking of pork meat — Physicochemical and sensory aspects. Meat Science, 118, 82-88.

Becker, A., Boulaaba, A., Pingen, S., Röhner, A., \& Klein, G. (2015). Low temperature, long time treatment of porcine M. longissimus thoracis et lumborum in a combi steamer under commercial conditions. Meat Science, 110, $230-235$. 
Beilken, S. L., Bouton, P. E., \& Harris, P. V. (1986). Some effects on the mechanical properties of meat produced by cooking at temperatures between $50^{\circ}$ and $60^{\circ} \mathrm{C}$. Journal of Food Science, 51, 791-796.

Beltrán, J. A., Bonnet, M., \& Ouali, A. (1992). Comparative action of cathepsins B and L on intramuscular collagen as assessed by differential scanning calorimetry. Meat Science, 32, 299-306.

Bendall, J. R., \& Restall, D. J. (1983). The cooking of single myofibres, small myofibre bundles and muscle strips from beef M. psoas and M. sternomandibularis muscles at varying heating rates and temperatures. Meat Science, 8, 93-117.

Berge, P., Ertbjerg, P., Larsen, L. M., Astruc, T., Vignon, X., \& Møller, A. J. (2001). Tenderization of beef by lactic acid injected at different times post mortem. Meat Science, 57, 347-357.

Berhe, D. T., Engelsen, S. B., Hviid, M. S., \& Lametsch, R. (2014). Raman spectroscopic study of effect of the cooking temperature and time on meat proteins. Food Research International, 66, 123-131.

Bertola, N. C., Bevilacqua, A. E., \& Zaritzky, N. E. (1994). Heat treatment effect on texture changes and thermal denaturation of proteins in beef muscle. Journal of Food Processing and Preservation, 18, 31-46.

Bertram, H. C., Aaslyng, M. D., \& Andersen, H. J. (2005). Elucidation of the relationship between cooking temperature, water distribution and sensory attributes of pork - a combined NMR and sensory study. Meat Science, 70, 75-81.

Botinestean, C., Keenan, D. F., Kerry, J. P., \& Hamill, R. M. (2016). The effect of thermal treatments including sous-vide, blast freezing and their combinations on beef tenderness of M. semitendinosus steaks targeted at elderly consumers. $L W T$ Food Science and Technology, 74, 154-159.

Bouton, P. E., \& Harris, P. V. (1981). Changes in the tenderness of meat cooked at 50-65 C. Journal of Food Science, 46, 475478.

Bouton, P. E., \& Harris, P. V. (1972a). A comparison of some objective methods used to assess meat tenderness. Journal of Food Science, 37, 218-221.

Bouton, P. E., \& Harris, P. V. (1972b). The effects of cooking temperature and time on some mechanical properties of meat. 
Journal of Food Science, 37, 140-144.

Bouton, P. E., Harris, P. V, Macfarlane, J. J., \& Snowden, J. M. (1977). The effects of long term cooking on shear force deformation curves. Journal of Texture Studies, 8, 297-310.

Bouton, P. E., Harris, P. V, \& Ratcliff, D. (1981). Effect of cooking temperature and time on the shear properties of meat. Journal of Food Science, 46, 1082-1087.

Bouton, P. E., Harris, P. V, \& Shorthose, W. R. (1976). Dimensional changes in meat during cooking. Journal of Texture Studies, 7 , 179-192.

Bramblett, V. D., Hostetler, R. L., Vail, G. E., \& Draudt, H. N. (1959). Qualities of beef as affected by cooking at very low temperatures for long periods of time. Food Technology, 13, 707-711.

Bramblett, V. D., \& Vail, G. E. (1964). Further studies on qualities of beef as affected by cooking at very low temperatures for long periods. Food Technology, 18, 245-.

Brüggemann, D. A., Brewer, J., Risbo, J., \& Bagatolli, L. (2010). Second harmonic generation microscopy: A tool for spatially and temporally resolved studies of heat induced structural changes in meat. Food Biophysics, 5, 1-8.

Buck, E. M., Hickey, A. M., \& Rosenau, J. (1979). Low-temperature air oven vs a water bath for the preparation of rare beef. Journal of Food Science, 44, 1602-1605.

Burleigh, M. C., Barrett, A. J., \& Lazarus, G. S. (1974). Cathepsin B1. A lysosomal enzyme that degrades native collagen. Biochemical Journal, 137, 387-398.

Califano, A. N., Bertola, N. C., Bevilacqua, A. E., \& Zaritzky, N. E. (1997). Effect of processing conditions on the hardness of cooked beef. Journal of Food Engineering, 34, 41-54.

Calkins, C. R., \& Hodgen, J. M. (2007). A fresh look at meat flavor. Meat Science, 77, 63-80.

Carmody, R. N., Weintraub, G. S., \& Wrangham, R. W. (2011). Energetic consequences of thermal and nonthermal food processing. PNAS, 108, 19199-19203. 
Chelh, I., Gatellier, P., \& Santé-Lhoutellier, V. (2006). Technical note: A simplified procedure for myofibril hydrophobicity determination. Meat Science, 74, 681-683.

Cheng, C.-S., \& Parrish, F. C. (1979). Heat-induced changes in, myofibrillar protein of bovine Longissimus muscle. Journal of Food Science, 44, 22-24.

Christensen, L., Bertram, H. C., Aaslyng, M. D., \& Christensen, M. (2011a). Protein denaturation and water-protein interactions as affected by low temperature long time treatment of porcine Longissimus dorsi. Meat Science, 88, 718-722.

Christensen, L., Ertbjerg, P., Aaslyng, M. D., \& Christensen, M. (2011b). Effect of prolonged heat treatment from $48^{\circ} \mathrm{C}$ to $63^{\circ} \mathrm{C}$ on toughness, cooking loss and color of pork. Meat Science, 88, 280-285.

Christensen, L., Ertbjerg, P., Løje, H., Risbo, J., van den Berg, F. W. J., \& Christensen, M. (2013). Relationship between meat toughness and properties of connective tissue from cows and young bulls heat treated at low temperatures for prolonged times. Meat Science, 93, 787-795.

Christensen, L., Gunvig, A., Tørngren, M. A., Aaslyng, M. D., Knøchel, S., \& Christensen, M. (2012). Sensory characteristics of meat cooked for prolonged times at low temperature. Meat Science, 90, 485-489.

Christensen, M., Larsen, L. M., Ertbjerg, P., \& Purslow, P. P. (2004). Effect of proteolytic enzyme activity and heating on the mechanical properties of bovine single muscle fibres. Meat Science, 66, 361-369.

Christensen, M., Purslow, P. P., \& Larsen, L. M. (2000). The effect of cooking temperature on mechanical properties of whole meat, single muscle fibres and perimysial connective tissue. Meat Science, 55, 301-307.

Church, I. J., \& Parsons, A. L. (2000). The sensory quality of chicken and potato products prepared using cook-chill and sous vide methods. International Journal of Food Science \& Technology, 35, 155-162.

Cover, S. (1943). Effect of extremely low rates of heat penetraton on tendering of beef. Journal of Food Science, 8, 388-394. Creed, P. G. (1995). The sensory and nutritional quality of 'sous vide' foods. Food Control, 6, 45-52.

Cross, H. R., Stanfield, M. S., \& Koch, E. J. (1976). Beef palatability as affected by cooking rate and final internal temperature. 
Journal of Animal Science, 43, 114-121.

Davey, C. L., \& Gilbert, K. V. (1974). Temperature-dependent cooking toughness in beef. Journal of the Science of Food and Agriculture, 25, 931-938.

Davey, C. L., \& Gilbert, K. V. (1976). The temperature coefficient of beef ageing. Journal of the Science of Food and Agriculture, 27, 244-250.

Davey, C. L., \& Niederer, A. F. (1977). Cooking tenderizing in beef. Meat Science, 1, 271-276.

Davey, C. L., Niederer, A. F., \& Graafhuis, A. E. (1976). Effects of ageing and cooking on the tenderness of beef muscle. Journal of the Science of Food and Agriculture, 27, 251-256.

Díaz, P., Nieto, G., Garrido, M. D., \& Bañón, S. (2008). Microbial, physical-chemical and sensory spoilage during the refrigerated storage of cooked pork loin processed by the sous vide method. Meat Science, 80, 287-292.

Dinardo, M., Buck, E. M., \& Clydesdale, F. M. (1984). Effect of extended cook times on certain physical and chemical characteristics of beef prepared in a waterbath. Journal of Food Science, 49, 844-848.

Duan, Z., Hansen, T. H., Hansen, T. B., Dalgaard, P., \& Knøchel, S. (2016). Predicting outgrowth and inactivation of Clostridium perfringens in meat products during low temperature long time heat treatment. International Journal of Food Microbiology, 230, 45-57.

Ertbjerg, P., Christiansen, L. S., Pedersen, A. B., \& Kristensen, L. (2012). The effect of temperature and time on activity of calpain and lysosomal enzymes and degradation of desmin in porcine longissimus muscle. 58th International Congress of Meat Science and Technology, 12-17 August. Montreal, Canada.

Ertbjerg, P., Mielche, M. M., Larsen, L. M., \& Møller, A. J. (1999). Relationship between proteolytic changes and tenderness in prerigor lactic acid marinated beef. Journal of the Science of Food and Agriculture, 79, 970-978.

Ertbjerg, P., \& Puolanne, E. (2017) Muscle structure, sarcomere length and influences on meat quality: A review. Meat Science, $132,139-152$. 
Etherington, D. J. (1976). Bovine spleen cathepsin B1 and collagenolytic cathepsin. A comparative study of the properties of the two enzymes in the degradation of native collagen. Biochemical Journal, 153, 199-209.

F.S.I.S. (2011). El USDA Revisa las Temperaturas Recomendadas para Cocinar Todos los Cortes Enteros de Carnes, Incluyendo Cerdo, a $145^{\circ} \mathrm{F}\left(62.8^{\circ} \mathrm{C}\right)$.

FDA, U. S. (2011). Fish and fishery products hazards and controls guidance. Food and Drug Administration, Center for Food Safety and Applied Nutrition, US Department of Health and Human Services. Http://www. Fda. gov/FoodGuidances (27 November 2017, Date Last Accessed).

Fraterman, S., Zeiger, U., Khurana, T. S., Wilm, M., \& Rubinstein, N. A. (2007). Quantitative proteomics profiling of sarcomere associated proteins in limb and extraocular muscle allotypes. Molecular \& Cellular Proteomics, 728.

García-Segovia, P., Andrés-Bello, A., \& Martínez-Monzó, J. (2007). Effect of cooking method on mechanical properties, color and structure of beef muscle (M. pectoralis). Journal of Food Engineering, 80, 813-821.

Graham, A. F., Mason, D. R., Maxwell, F. J., \& Peck, M. W. (1997). Effect of pH and NaCl on growth from spores of nonproteolytic Clostridium botulinum at chill temperature. Letters in Applied Microbiology, 24, 95-100.

Grigioni, G. M., Margaría, C. A., Pensel, N. A., Sánchez, G., \& Vaudagna, S. R. (2000). Warmed-over flavour analysis in low temperature-long time processed meat by an 'electronic nose'. Meat Science, 56, 221-8.

Gunvig, A., Jacobsen, T., \& Tørngren, M. A. (2012). How to make safe, juicy and rose beef patties for the food service sector. 58th International Congress of Meat Science and Technology 12-17 August 2012, Montreal, Canada.

Hansen, T. B., \& Knøchel, S. (1996). Thermal inactivation of Listeria monocytogenes during rapid and slow heating in sous vide cooked beef. Letters in Applied Microbiology, 64, 425-428.

Hansen, T. B., Knøchel, S., Juncher, D., \& Bertelsen, G. (1995). Storage characteristics of sous vide cooked roast beef. International Journal of Food Science \& Technology, 30, 365-378.

Hesser, A. (2005). Under pressure. The New York Times. August, 14. 
Holdsworth, S. D., \& Simpson, R. (2007). Thermal processing of packaged foods. New York: Springer.

Hughes, J. M., Oiseth, S. K., Purslow, P. P., \& Warner, R. D. (2014). A structural approach to understanding the interactions between colour, water-holding capacity and tenderness. Meat Science, 98, 520-532.

Hunt, M. C., Sørheim, O., \& Slinde, E. (1999). Color and heat denaturation of myoglobin forms in ground beef. Journal of Food Science, 64, 847-851.

Hyytia-Trees, E., Skytta, E., Mokkila, M., Kinnunen, A., Lindstrom, M., Lahteenmaki, L., ... Korkeala, H. (2000). Safety evaluation of sous vide-processed products with respect to nonproteolytic Clostridium botulinum by use of challenge studies and predictive microbiological models. Applied and Environmental Microbiology, 66, 223-229.

Juneja, V. K., Bari, M. L., Inatsu, Y., Kawamoto, S., \& Friedman, M. (2009). Thermal destruction of Escherichia coli 0157:H7 in sous-vide cooked ground beef as affected by tea leaf and apple skin powders. Journal of Food Protection, 72, 860-865.

Juneja, V. K., \& Marmer, B. S. (1998). Thermal inactivation of Clostridium perfringens vegetative cells in ground beef and turkey as affected by sodium pyrophosphate. Food Microbiology, 15, 281-287.

Kovácsné Oroszvári, B., Rocha, C. S., Sjöholm, I., \& Tornberg, E. (2006). Permeability and mass transfer as a function of the cooking temperature during the frying of beefburgers. Journal of Food Engineering, 74, 1-12.

King, N. J., \& Whyte, R. (2006). Does it look cooked? A review of factors that influence cooked meat color. Journal of Food Science, 71, R31-R40.

Kristensen, L., \& Purslow, P. P. (2001). The effect of ageing on the water-holding capacity of pork: Role of cytoskeletal proteins. Meat Science, 58, 17-23.

Laakkonen, E., Sherbon, J. W., \& Wellington, G. H. (1970). Low-temperature, long-time heating of bovine muscle 3. Collagenolytic Activity. Journal of Food Science, 35, 181-184.

Laakkonen, E., Wellington, G. H., \& Sherbon, J. N. (1970). Low-temperature, long-time heating of bovine muscle 1. Changes in tenderness, water-binding capacity, pH and amount of water-soluble components. Journal of Food Science, 35, $175-177$. 
Lepetit, J. (2007). A theoretical approach of the relationships between collagen content, collagen cross-links and meat tenderness. Meat Science, 76, 147-159.

Lewis, G. J., \& Purslow, P. P. (1989). The strength and stiffness of perimysial connective tissue isolated from cooked beef muscle. Meat Science, 26, 255-269.

Lindström, M., Mokkila, M., Skyttä, E., Hyytiä-Trees, E., Lähteenmäki, L., Hielm, S., ... Korkeala, H. (2001). Inhibition of growth of nonproteolytic Clostridium botulinum type B in sous vide cooked meat products is achieved by using thermal processing but not nisin. Journal of Food Protection, 64, 838-44.

Liu, J., Arner, A., Puolanne, E., \& Ertbjerg, P. (2016). On the water-holding of myofibrils: Effect of sarcoplasmic protein denaturation. Meat Science, 119, 32-40.

Liu, J., Puolanne, E., \& Ertbjerg, P. (2014). Temperature induced denaturation of myosin: Evidence of structural alterations of myosin subfragment-1. Meat Science, 98, 124-128.

Machlik, S. M., \& Draudt, H. N. (1963). The effect of heating time and temperature on the shear of beef semitendinosus muscle. Journal of Food Science, 28, 711-718.

Mancini, R. A., \& Hunt, M. C. (2005). Current research in meat color. Meat Science, 71, 100-121.

Martens, H., Stabursvik, E., \& Martens, M. (1982). Texture and colour changes in meat during cooking related to thermal denaturation of muscle proteins1. Journal of Texture Studies, 13, 291-309.

Micklander, E., Peshlov, B., Purslow, P. P., \& Engelsen, S. B. (2002). NMR-cooking: monitoring the changes in meat during cooking by low-field 1H-NMR. Trends in Food Science \& Technology, 13, 341-346.

Møller, A. J. (1981). Analysis of Warner-Bratzler shear pattern with regard to myofibrillar and connective tissue components of tenderness. Meat Science, 5, 247-260.

Mortensen, L. M., Frøst, M. B., Skibsted, L. H., \& Risbo, J. (2012). Effect of time and temperature on sensory properties in lowtemperature long-time sous-vide cooking of beef. Journal of Culinary Science \& Technology, 10, 75-90. 
Mortensen, L. M., Frøst, M. B., Skibsted, L. H., \& Risbo, J. (2015). Long-time low-temperature cooking of beef: three dominant time-temperature behaviours of sensory properties. Flavour, 4, 2.

Mottram, D. S. (1998). Flavour formation in meat and meat products: a review. Food Chemistry, 62, 415-424.

Mutungi, G., Purslow, P., \& Warkup, C. (1996). Influence of temperature, fibre diameter and conditioning on the mechanical properties of single muscle fibres extended to fracture. Journal of the Science of Food and Agriculture, 72, 359-366.

Myhrvold, N., Young, C., Bilet, M., \& Smith, R. M. (2011). Modernist cuisine: The art and science of cooking. Cooking Lab, Bellevue, WA.

Obuz, E., Dikeman, M. E., Erickson, L. E., Hunt, M. C., \& Herald, T. J. (2004). Predicting temperature profiles to determine degree of doneness for beef biceps femoris and longissimus lumborum steaks. Meat Science, 67, 101-105.

Oillic, S., Lemoine, E., Gros, J.-B., \& Kondjoyan, A. (2011). Kinetic analysis of cooking losses from beef and other animal muscles heated in a water bath - Effect of sample dimensions and prior freezing and ageing. Meat Science, 88, 338-346.

Pacifici, R. E., Kono, Y., \& Davies, K. J. (1993). Hydrophobicity as the signal for selective degradation of hydroxyl radicalmodified hemoglobin by the multicatalytic proteinase complex, proteasome. The Journal of Biological Chemistry, 268, 15405-15411.

Palka, K. (2003). The influence of post-mortem ageing and roasting on the microstructure, texture and collagen solubility of bovine semitendinosus muscle. Meat Science, 64, 191-198.

Palka, K., \& Daun, H. (1999). Changes in texture, cooking losses, and myofibrillar structure of bovine M. semitendinosus during heating. Meat Science, 51, 237-243.

Peck, M. W., \& Stringer, S. C. (2005). The safety of pasteurised in-pack chilled meat products with respect to the foodborne botulism hazard. Meat Science, 70, 461-475.

Pegg, R. B., \& Shahidi, F. (2014). Cooking of meat | Flavor Development. In M. Dikeman \& C. Devine (Eds.), Encyclopedia of Meat Sciences (Second Edition) (pp. 377-384). Oxford: Academic Press. 
Penfield, M. P., \& Meyer, B. H. (1975). Changes in tenderness and collagen of beef semitendinosus muscle heated at two rates. Journal of Food Science, 40, 150-154.

Purslow, P. (2016). Parasitic zoonoses present some risks with low-temperature cooking of pork. Meat Science, 119, 14-15. Qi, J., Li, X., Zhang, W., Wang, H., Zhou, G. \& Xu, X. (2017) Influence of stewing time on the texture, ultrastructure and in vitro digestetibility of meat from the yellow-feathered chicken breed. Animal Science Journal, in press.

Resurreccion, A. V. A. (2004). Sensory aspects of consumer choices for meat and meat products. Meat Science, 66, 11-20.

Rinaldi, , M., Dall'Asta, C., Paciulli, M., Cirlini, M., Manzi, C., \& Chiavaro, E. (2014) A novel time/temperature approach to sous vide cooking of beef muscle. Food and Bioprocess Technology, 7, 2969-2977.

Roldán, M., Antequera, T., Armenteros, M., \& Ruiz, J. (2014). Effect of different temperature-time combinations on lipid and protein oxidation of sous-vide cooked lamb loins. Food Chemistry, 149, 129-136.

Roldán, M., Antequera, T., Martín, A., Mayoral, A. I., \& Ruiz, J. (2013). Effect of different temperature-time combinations on physicochemical, microbiological, textural and structural features of sous-vide cooked lamb loins. Meat Science, 93, 572578.

Roldán, M., Ruiz, J., Sánchez del Pulgar, J., Pérez-Palacios, T., \& Antequera, T. (2015). Volatile compound profile of sous-vide cooked lamb loins at different temperature-time combinations. Meat Science, 100, 52-57.

Ruiz, J., Ventanas, J., Cava, R., Andrés, A., \& García, C. (1999). Volatile compounds of dry-cured Iberian ham as affected by the length of the curing process. Meat Science, 52, 19-27.

Salaseviciene, A., Vaiciulyte-Funk, L., \& Koscelkovskienė, I. (2014). Impact of low temperature, prolonged time treatment and vacuum depth on the porcine muscle quality and safety. In 9th Baltic Conference on Food Science and Technology 'Food for Consumer Well-Being' (Vol. 16649, p. 333).

Sánchez del Pulgar, J., Gázquez, A., \& Ruiz-Carrascal, J. (2012). Physico-chemical, textural and structural characteristics of sousvide cooked pork cheeks as affected by vacuum, cooking temperature, and cooking time. Meat Science, 90, 828-835. 
Sánchez del Pulgar, J., Roldán, M., \& Ruiz-Carrascal, J. (2013). Volatile compounds profile of sous-vide cooked pork cheeks as affected by cooking conditions (vacuum packaging, temperature and time). Molecules, 18, 12538-12547.

Santé-Lhoutellier, V. S., Astruc, T., Marinova, P., Greve, E., \& Gatellier, P. (2008). Effect of meat cooking on physicochemical state and in vitro digestibility of myofibrillar proteins. Journal of Agricultural and Food Chemistry, 56, 1488-1494.

Santé-Lhoutellier, V. S., Théron, L., Cepeda, M., Grajales, A., \& Gatellier, P. (2008). Comparison of proteolysis in native, heattreated and aged proteins from turkey meat. British Poultry Science, 49, 308-314.

Sheard, M. A., \& Rodger, C. (1995). Optimum heat treatments for 'sous vide' cook-chill products. Food Control, 6, 53-56. Smith, A. M., Evans, D. A., \& Buck, E. M. (1981). Growth and Survival of Clostridium perfringens in Rare Beef Prepared in a Water Bath. Journal of Food Protection, 44, 9-14.

Spanier, A. M., McMillin, K. W., \& Miller, J. A. (1990). Enzyme activity levels in beef: Effect of postmortem aging and end-point cooking temperature. Journal of Food Science, 55, 318-322.

Sun, Y., Chen, W.-L., Lin, S.-J., Jee, S.-H., Chen, Y.-F., Lin, L.-C., ... Dong, C.-Y. (2006). Investigating Mechanisms of Collagen Thermal Denaturation by High Resolution Second-Harmonic Generation Imaging. Biophysical Journal, 91, 2620-2625.

Tornberg, E. (2005). Effects of heat on meat proteins - Implications on structure and quality of meat products. Meat Science, 70, 493-508.

Trout, G. R. (1989). Variation in myoglobin denaturation and color of cooked beef, pork, and turkey meat as influenced by pH, sodium chloride, sodium tripolyphosphate, and cooking temperature. Journal of Food Science, 54, 536-540.

Vaudagna, S., Sanchez, G., Neira, M. S., Insani, E. M., Picallo, A. B., Gallinger, M. M., \& Lasta, J. A. (2002). Sous vide cooked beef muscles: effects of low temperature-long time (LT-LT) treatments on their quality characteristics and storage stability. International Journal of Food Science and Technology, 37, 425-441.

Voutila, L., Ruusunen, M., \& Puolanne, E. (2008). Comparison of the thermal characteristics of connective tissue in loose structured and normal structured porcine M. semimembranosus. Meat Science, 80, 1024-1030. 
Wagner, J. R., \& Anon, M. C. (1985). Denaturation kinetics of myofibrillar proteins in bovine muscle. Journal of Food Science, 50, 1547-1550.

Warner, R. D., Kauffman, R. G., \& Greaser, M. L. (1997). Muscle protein changes post mortem in relation to pork quality traits. Meat Science, 45, 339-352.

Warner, R. D., McDonnell, C. K., Bekhit, A. E. D., Claus, J., Vaskoska, R., Sikes, A. ... Ha (2017). Sytsematic review of emerging and innovative technologies for meat tenderisation. Meat Science, 132, 72-89.

Yu, T.-Y., Morton, J. D., Clerens, S., \& Dyer J. M. (2017) Cooking-induced protein modifications in meat. Comprehensive Reviews in Food Science and Food Safety, 16, 141-159.

Zeng, Z., Li, C., \& Ertbjerg, P. (2017). Relationship between proteolysis and water-holding of myofibrils. Meat Science, 131, 4855.

Zielbauer, B. I., Franz, J., Viezens, B., \& Vilgis, T. A. (2016). Physical aspects of meat cooking: Time dependent thermal protein denaturation and water loss. Food Biophysics, 11, 34-42. 